1987

\title{
Are We to Be a Nation?: The Making of the Constitution
}

Richard B. Bernstein

New York Law School, richard.bernstein@nyls.edu

Kym S. Rice

Follow this and additional works at: https://digitalcommons.nyls.edu/fac_books

\section{Recommended Citation}

Bernstein, Richard B. and Rice, Kym S., "Are We to Be a Nation?: The Making of the Constitution" (1987). Books. 68.

https://digitalcommons.nyls.edu/fac_books/68

This Article is brought to you for free and open access by the Faculty Scholarship at DigitalCommons@NYLS. It has been accepted for inclusion in Books by an authorized administrator of DigitalCommons@NYLS. 


\section{ARE WE TO BE A NATION?}

\section{The Making of the Constitution}

\section{RICHARD B. BERNSTEIN with Kym S. Rice}

HARVARD UNIVERSITY PRESS

CAMBRIDGE, MASSAGHUSETTS, AND LONDON, ENGLAND 1987 
Copyright (C 1987 by The New York Public Library All rights reserved

Printed in the United States of America

$\begin{array}{llllllllll}10 & 9 & 8 & 7 & 6 & 5 & 4 & 3 & 2 & 1\end{array}$

This book is printed on acid-free paper, and its binding materials have been chosen for strength and durability.

Set in Linotron Baskerville and designed by Marianne Perlak

Library of Congress Cataloging-in-Publication Data

Bernstein, Richard B., 1956-

Are we to be a nation?

Bibliography: p.

Includes index.

1. United States. Constitutional Convention (1787)

2. United States-Constitutional history. I. Rice, Kym S.

II. Title.

KF 4520.B47 $1987 \quad 34^{2.73^{\prime O 29}} \quad 86-19590$

ISBN 0-674-04475-4 (alk. paper) 347.302 29

ISBN $0-674-04476-2$ (pbk. : alk. paper) 


\section{CONTENTS}

Foreword Richard B. Morris ix

Preface Vartan Gregorian xi

1. Prologue: The State of the Union in the 1780 ,

2. A New Government for a New Nation 11

Creating the Confederation

Achievements at Home and Abroad

3. An Age of Experiments in Government

An Epoch of Constitution-Making

Revising the Laws

The Experience of the Loyalists

4. The Confederation in Quandary

"The Imbecility of Our Government"

The Rise of a Reform Movement

5. The Great Confluence

The Americans' Uses of Western Culture

The Problem of America in European Thought

John Adams Confronts the Philosophes

6. An Assembly of Demigods?

Exercises in Creative Statesmanship

Frustration and Deadlock in the New York Delegation

7. The Struggle for Ratification

The First National Political Campaign

The Argument over the Constitution

The Federalist

8. Under the Constitution

The Beginnings of Government

The Adoption of the Bill of Rights 
Chronology

Delegates to the Federal Convention of 1787 284

Notes 285

List of Illustrations 320

Acknowledgments 328

Index 


\section{PROLOGUE: \\ THE STATE OF THE UNION \\ IN THE 1780s}

$\mathrm{T}$

HE CONSTITUTION of the United States was the product of a revolution in political thought at least as important and far-reaching as the winning of American independence from Great Britain. The battles of this revolution were contests of speeches, pamphlets, and votes-not of shot and shell; its battlegrounds were constitutional conventions and legislative sessions-not redoubts or besieged cities; and its relics and monuments are instruments and institutions of government-not tattered flags or rusting weapons. The American experiments in self-government in the Revolutionary era were a critical part of our attempts to define our identity as a nation, and the making of the federal Constitution was the culmination of the intellectual ferment and political experimentation in the new republic.

By MAY of 1787 , the month that saw the opening of the Federal Convention, the United States of America had been an independent nation for just over a decade and a nation at peace for less than five years. Yet, as successor to the colonial system known as British North America, the United States also embodied one hundred seventy years of continuous British presence in the New World. The thirteen American states may have seemed rustic and provincial to the citizens of London, Paris, Madrid, or Vienna. Nonetheless, they had mastered the art of politics, had evolved a thriving and complex society, and were in the process of formulating a national social, economic, and cultural identity.

By far the most astonishing aspect of the United States was its size. From north to south the new nation spanned about twelve hundred miles, and from the Atlantic coast to the Mississippi River approximately six hundred. Any of the thirteen American states was at least as large as a medium-sized European nation, and England itself could have just about fit within the state of New York. The United States seemed blessed almost beyond imagining with natural resources and especially with room for growth. Even if the American population doubled every twenty years, as Benjamin Franklin predicted in 1751 , there still seemed room enough in the new republic for "the thousandth and thousandth generation," as Thomas Jefferson confidently asserted in 1801.1 


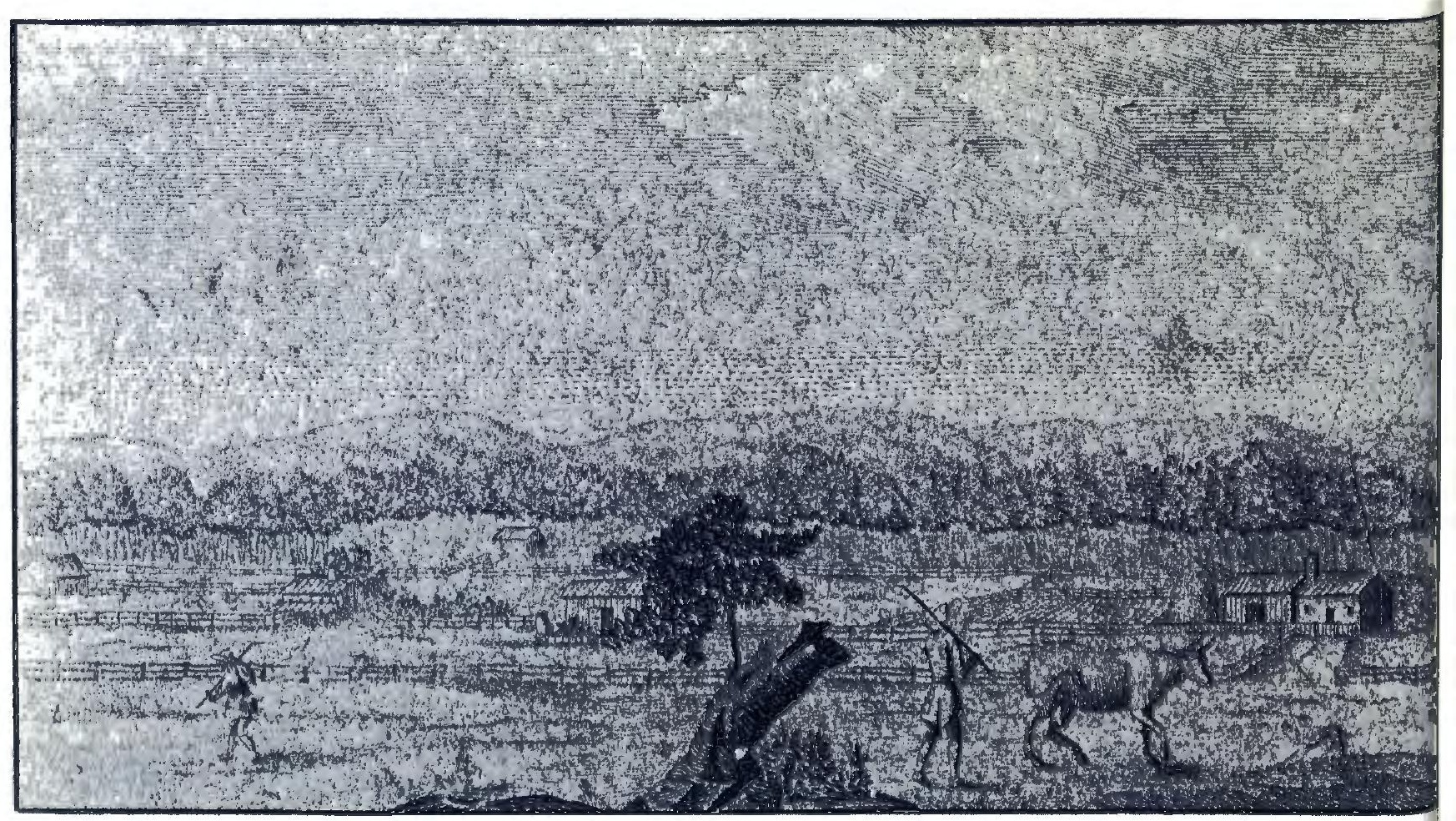

Although the United States was the largest nation in the Western world except Russia, its population was comparatively sparse. Fewer than four million inhabitants occupied the populated strip extending about two hundred miles inward from the Atlantic coast (Figure 1.1). Beyond this frontier lay the territory acquired from Great Britain after the Revolution; this area was largely the domain of Indian tribes, with a scattering of American and British military posts. The British maintained a military presence in this territory despite the stipulation in the Treaty of Paris of 1783 that these forts were to be evacuated; they argued that they were entitled to keep their forts until the Americans fulfilled their obligation under the treaty to pay debts owed to British creditors.

The Americans were for the most part a nation of farmers, although a few farseeing writers such as Tench Coxe predicted a glorious future for the United States as a manufacturing and commercial nation. ${ }^{2}$ Even the tenth of the population who practiced the professions-lawyers, doctors, and the clergy-never fully abandoned agriculture as a source of income or provisions. Agriculture's economic centrality made it central also to the political and social thinking of most Americans. ${ }^{3}$ Of the seven of every ten Americans who earned their livelihood by working on small farms, three were laborers on farms owned by others, whereas four owned the land they tilled. Most of these farms consisted of about ninety-six to one hundred sixty acres, but only a few acres were in active cultivation; the rest were used for pasture for livestock or for growing timber or were left fallow. Even so,

Figure I.I

Artist unknown. View upon the Road from New-Windsor, towards Morris Town Jersey. Line engray ing, 1789 . 
these farms required the full commitment of a farmer and his wife, their children, and hired help-or, in the South, the labor of a few slaves-and as a result most Americans rarely saw anyone outside their own household on a day-to-day basis. They did travel on occasion, usually to the nearest town to buy provisions that they could not grow or produce themselves, to sell their cash crops, and to find out the latest news. If they were members of a church, they might also make the effort to attend religious services, although by the late eighteenth century church membership and attendance were on the decline. The lives of most Americans in this era were closely tied to the rhythms of the agricultural economy, with its cycles of plantings and harvests (Figure 1.2). Their existence was a hard one, with few amenities or opportunities for entertainment, but their standard of living was highin many ways the highest in the Western world. ${ }^{4}$

Most Americans did not take an active part in the political life of the new republic, contenting themselves with voting if they met the requirements established by state constitutions and laws. All the states maintained some form of property test for voting and still higher property qualifications for holding elective office. ${ }^{5}$ These requirements grew out of a few basic assumptions about political life that dominated the thinking of the eighteenth century: first, one ought to have a stake in society and be able to prove it before one could have a voice in directing that society's affairs; second, only truly independent voters, whose independence could be proved by their ability to satisfy the property test, were desirable participants in political life. Just how many Americans did meet these property tests for voting in this period is a matter of vigorous historical dispute, though it now seems that the property tests were far easier to satisfy than was previously believed. Of the fraction of the total population who could play a role in the political process, however, few aspired to hold office. The society that had evolved since the first British settlements at Jamestown.in 1607 was governed by unspoken assumptions and principles bound up in the shorthand term deference. There were basically two kinds of Americans: gentlemen, who did not need to worry about earning a livelihood and thus were well suited to hold office and shape policy; and everyone else, usually grouped as "the common sort." For the most part, the common sort did not challenge the assumption that the elite were entitled to dominate the political system, but the deferential society of colonial America was buffeted and weakened by the doctrines let loose by the Revolution, and as a result the distinction between gentlemen and the common sort began to erode in the 1770 and $1780 .^{6}$

This distinction was not a rigidly defined class barrier of the type found in Europe; in Denmark, for example, there existed a nine-class system in which it was a crime for members of the upper three classes to interact with members of the lower six. ${ }^{7}$ It was possible for the tenth son of a Boston tallow chandler, a runaway apprentice, to come to Philadelphia virtually penniless and eventually become wealthy, respected, and powerful-this was 


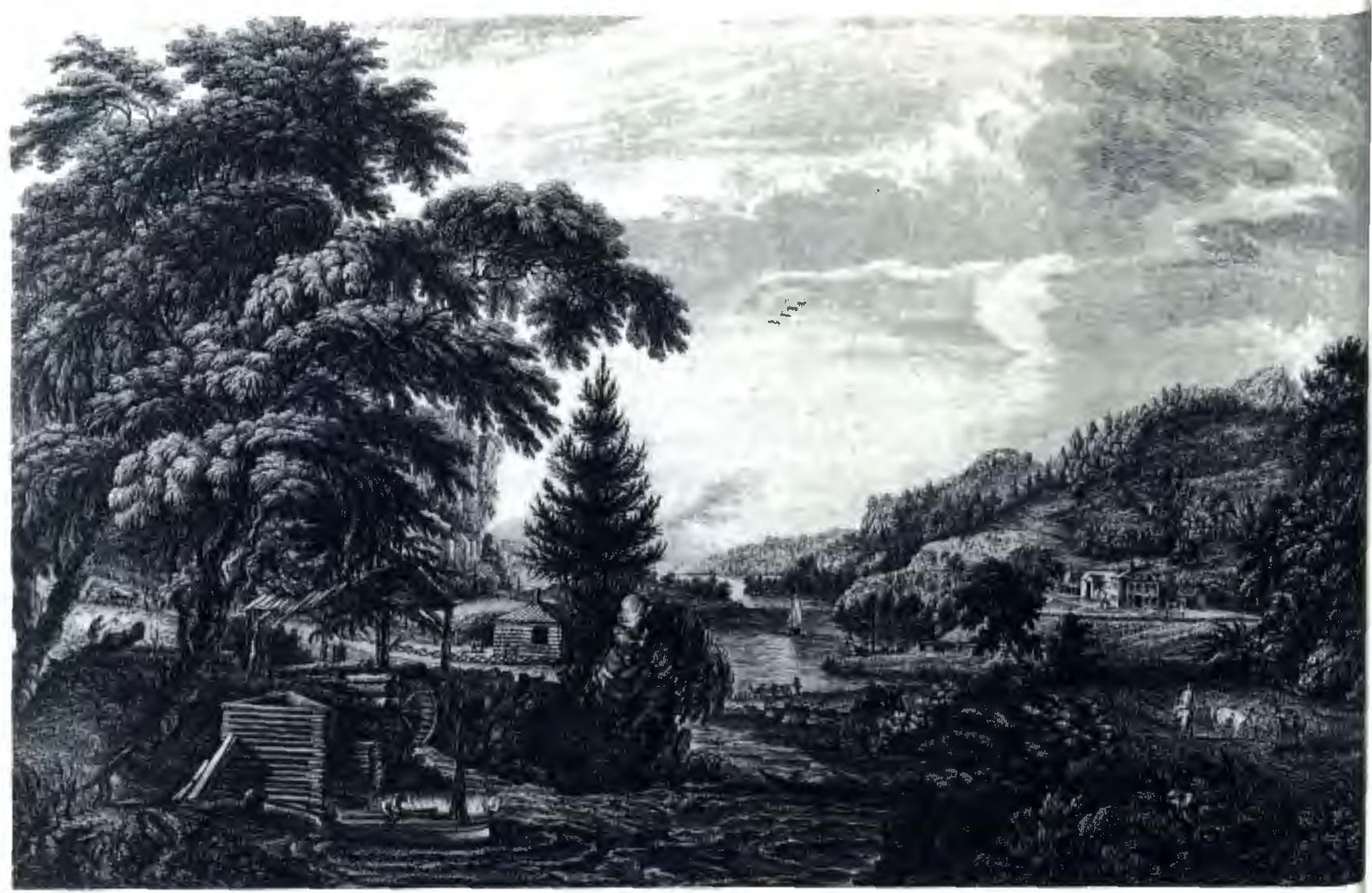

the achievement of the great Dr. Franklin, who became a symbol of the possibilities of America to his admiring compatriots. Similarly, a brilliant illegitimate child could find backing to be educated at King's College (now Columbia University) and become a pillar of the New York legal profession as well as one of the ablest and most respected proponents of a stronger national government-such was the climb of Alexander Hamilton, who nonetheless strove to obscure the circumstances of his early life. The idea of the self-made man was thus an early development in American thought, though it was still the exception rather than the rule. ${ }^{8}$

In addition, the elite of American society were themselves heterogeneous, divided by occupation, education, religion, and geography. New England divines, merchants, and lawyers found it difficult to establish common ground with southern planters, and vice versa. The cleavages and divergences between the various states and regions that made up the United States were among the most daunting obstacles to forging a union of the American states.

Whatever the structure of American politics and the fluid and evanescent quality of the distinctions between the elite and the common sort, several key groups were excluded by common consent even from the common sort and thus had no direct role in shaping American politics-Indians, blacks, women, and the desperately poor or debtor class.

Figure 1.2

James Peake after Paul Sandb) after Governor Thomas Pown? A Design to represent the beginnit and completion of an American Settlement or Farm. Line engrav ing, 1768 . 
Of these groups, the Indians loomed largest in the minds of most Americans. ${ }^{9}$ From the outset, native Americans had viewed the Europeans' colonization of North America with puzzlement and suspicion. They had at first sought to help the struggling settlements but soon realized that their differing views on the concept of land ownership and exploitation of natural resources made such cooperation impossible. Some tribes maintained friendly or "arm's-length" relations with the colonial governments and later with the states and the Confederation; others withdrew from contact or sought to drive the new settlers out of North America by waging war. During the colonial wars of the seventeenth and eighteenth centuries, the British and French forged alliances with various Indian tribes, and the outcomes of those conflicts spelled extinction for tribes unfortunate enough to be allies of the losing imperial power; similar alliances were made during the Revolution, with similar consequences. By the mid-1780s, most Americans had at least heard rumors of the "savagery" or "barbarism" of the Indians' methods of warfare, if they had not actually witnessed it; consequently, in frontier settlements in the West and South, fear of Indian attacks prompted settlers to support a strong general government that could field and support an army to repel such attacks and preserve their security.

In Virginia, in the same year that witnessed the founding of the Virginia House of Burgesses, a ship bearing twenty "Nigars" docked in Jamestown harbor. These first black residents of British North America were indentured servants, who had committed themselves to work for a term of years as deferred payment for their passage to Virginia. Within a generation, however, the white settlers had laid the foundations for the system of chattel slavery. ${ }^{10}$ By 1787 , the black population of the United States numbered some $65^{\circ}, 000$, most of whom were slaves. Slavery existed in nearly every state, though many northern states were either contemplating or moving toward abolition of the institution. ${ }^{11}$ Most slaveholders lived in the southern states, where the cultivation of labor-intensive crops such as tobacco, rice, and indigo made dependence on slave labor necessary. Large slaveholding estates, however, were the exception rather than the rule. Most slaveholders owned fewer than five slaves; few operated on the scale of Virginia's George Mason, who owned as many as ninety slaves to till his seventy-five-thousandacre plantation, Gunston Hall. These slaves were deemed to be property, pure and simple, ${ }^{12}$ though their lives were not as harsh as those of their descendants in the next century, the age of King Cotton.

Nonetheless, the institution of chattel slavery was a blight on the new republic, distorting and crippling opportunities for the comparatively few free blacks in the North and condemning hundreds of thousands of men, women, and children to lives of unremitting toil and degradation. Furthermore, the issue of slavery threatened the political stability of the United States. ${ }^{13}$ In the 1770 and 1780 s, distinguished northerners such as Benjamin Franklin, Benjamin Rush, and John Jay founded or joined manumission societies and campaigned for the abolition of slavery. Enlightened southerners such as Washington, Jefferson, Mason, and Madison hoped that slavery 
somehow would eventually wither away, though they took few steps themselves to help bring this about. Other southerners, such as the Rutledges and Pinckneys of South Carolina, defended the institution as a necessary part of the plantation economy and the southern way of life, and even as a positive good for the slaves themselves. Slavery thus had the potential to cause irreparable cleavage in the American political community, and most politicians of the period regarded it as a problem to be handled with extreme care-if indeed at all.

The role of women in American society in the Revolutionary era is one of the major new fieids of historical inquiry. ${ }^{14}$ Recent scholarship has illuminated not only this specific subject but also the general character of the Revolution. Most women in this period found themselves consigned largely to the private realm of home, family, and childbearing and -rearing. Some women, such as the Baltimore printer Mary K. Goddard or the historian, poet, dramatist, and polemicist Mercy Otis Warren of Boston, were able to lead their own lives and take at least some part in the public controversies of the day. Nonetheless, the prevailing legal and political assumptions of colonial America persisted into the Revolutionary period. Although academies for young women brought literacy and learning to some, it was a matter of controversy whether women should be educated at all, on the rationale that education would only tend to make them dissatisfied with their place in society. Married women were still subject to the common-law doctrine of coverture, under which a married couple was considered as one person-the husband; married women thus had no claim to property during the existence of their marriage. As Linda $\mathrm{K}$. Kerber has pointed out, thanks to the old political assumptions linking property with political rights and participation, the conventional wisdom concluded that married women had no capacity to play a role in political affairs. Nonetheless, the Revolution had profound consequences for the role of women in politics and society. The various economic boycotts of British goods in the pre-Revolutionary period depended for their effectiveness on the cooperation of women (Figure 1.3), and gradually, painfully, a theory of patriotism applicable to women began to coalesce. Women also came to play critical roles in the fighting of the Revolution itself-not as combatants, but in the equally crucial role of providing logistical support for the Continental Army, such as food, cleaning, nursing, clothing, and even intelligence work. The doctrine of coverture also raised issues of loyalty and patriotism when the new states and the Revolutionary government came to consider the plight of wives of Loyalists: were they bound to their husbands' choices of allegiance under law, unable legally to make political choices on their own, or did they have independent political capacity?

Choices such as these required women in the Revolutionary era to rethink the old view that they were exclusively creatures of the private sphere and must leave the public sphere of politics, diplomacy, and war to men. Indeed, the wives of a few key Revolutionary leaders showed themselves equal to many of their husbands and male kinsmen in their grasp of 


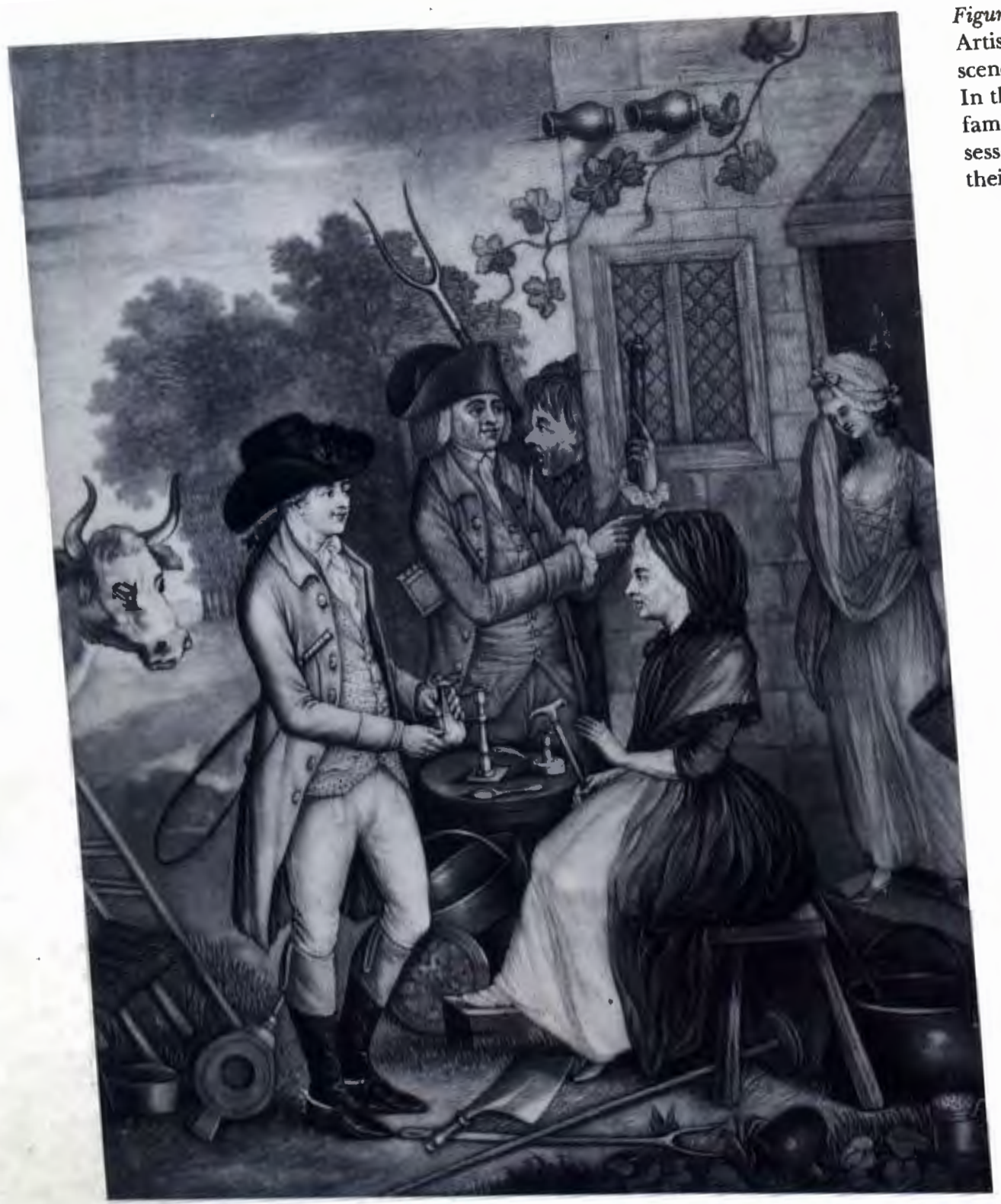

Figure 1.4

Artist unknown. A basıknuptc sene. Mezzotint, ca. $175^{0} \mathrm{v}^{-18}$ In this British caricature a family's belongings are repos: ed the authorities to $P$ heir debts.

and slave blacks, nor the Indians, but those who were too poor to have a legitimate voice in politics-in a popular phrase of the time, the "desperate debtors." 16 Many people, male and female, came to the British colonies and later to the United States as indentured servants, to pay for their passage from Europe. Indentured servants were not treated as property in theory or in practice, and they also knew that they were bound only for a finite period; in all other respects, however, they were virtually indistinguishable from chattel slaves. ${ }^{17}$

Those who were not bound for service were not immune from economic collapse. Because there was very little specie, or hard cash, in the United 
States in this period, the dominant medium of exchange was the note. The person making the note would promise to pay a specified sum at a specified date in exchange for goods or services to be provided by the person to whom he gave the note. The recipients of these notes then endorsed them over to other persons in payment for other goods and services; thus the economic life of the period ran on these written statements of credit and debt. The hope of the maker of a note was that, by the time the note became due or was presented to him for payment, he would have accumulated enough hard currency or other notes to be able to satisfy the obligation. Unfortunately, thanks to the uncertainties of agriculture and of commerce, many Americans' notes came back to them at times when they could not satisfy the demands.

The problem of debt affected Americans at every level of society (Figure 1.4). ${ }^{18}$ Many wealthy planters actually had to carry mountainous loads of debt, which on occasion brought them crashing down to ruin; so Thomas Jefferson discovered in the last years of his life, when the creditors of Wilson Cary Nicholas, for whom he had cosigned a note, came to Jefferson to satisfy the note when Nicholas defaulted. Associate Justice James Wilson of the Supreme Court died, senselessly raving, in a small inn in North Carolina, pursued by creditors after his huge and impracticable financial speculations disintegrated, leaving him and his family destitute. But the problem of debt struck most often and most cruelly at the small farmers and tradesmen; for every failure of a Jefferson or a Wilson, there were hundreds if not thousands of failures of much smaller scale, though equally catastrophic for the debtors involved. In some states, those who owed debts sought to induce the state governments to cause inflation by printing new issues of paper money; by flooding the money supply with depreciated currency, they reasoned, they could pay off their debts more quickly and exorcise the twin specters of litigation and debtor's prison. This pattern of inflationary politics appeared most frequently in Rhode Island, giving the tiny state an almost unshakable reputation for turbulence, faithlessness, and radicalism. This fear of Rhode Island's and other states' actions to cause inflation, to impede out-of-state and British creditors from collecting debts, and otherwise to vitiate or destroy the value of debts owed by their citizens was a major stimulus to the efforts to strengthen the general government of the United States.

American society in the 1770 s and 1780 s was thus a rich mosaic of groups, interests, and social strata, and it seems almost incredible that such a crazy-quilt collection of people could coalesce into a nation. Nonetheless, the American people were able to forge a national identity and sense of purpose that strengthened as the century drew to a close. This emergent nationalism was the product of several factors. ${ }^{19}$ For one thing, the Americans all spoke a common language, though there were regional variations in dialect and an occasional pocket of people like the Dutch-speaking patroons of the upper Hudson River valley in New York. For another, despite the sectarian differences between Congregationalists and Baptists, between Anglicans and Presbyterians, most Americans in this period shared the 
common religious heritage of Protestant Christianity-although, again, there were scattered pockets of Catholics in Maryland and other middle Atlantic states and a handful of Jews in New York, Rhode Island, and Philadelphia. ${ }^{20}$ Despite local loyalties, many Americans who pursued a college education crossed state lines to do so; southerners occasionally attended Harvard, Yale, or Princeton, and northerners enrolled in the new university in Philadelphia. ${ }^{21}$ Similarly, learned societies sprang up in the new republic and attracted members from all over America; the American Philosophical Society of Philadelphia and the American Academy of Boston are but two examples. ${ }^{22}$

Ultimately, however, what united the Americans, whether members of the elite or the common sort or even those ordinarily excluded from politics, was the experience of the Revolution itself. ${ }^{23}$ The Revolution compelled citizens of different states to consider the possibility that they were more than New Yorkers or Pennsylvanians or Georgians. The idea gradually emerged that there might be a national interest and common good transcending state and local loyalties and interests. Especially for those who served in the Confederation Congress or the Continental Army, the idea of an American nation took on a reality and an immediacy that eventually translated themselves into political action. Because the Revolution essentially focused on issues of political theory and questions of governmental structure and powers, the idea of national identity was intimately bound up with conceptions of politics. And the reverse was true, as well: once they were willing to conceive of the United States of America as a nation rather than as a collection of autonomous states, the Americans were ready to risk new political experiments to construct a national government. 